\title{
Efektivitas Peraturan Daerah Nomor 9 Tahun 2014 tentang Ketahanan Keluarga dalam Upaya Menekan Angka Perceraian di Jawa Barat
}

The Effectiveness of Regional Regulation Number 9 of 2014 Concerning the Implementation of Family Resilience Development in Efforts to Impress Divorce Numbers in West Java

\author{
Rinrin Warisni Pribadi \\ Sekolah Tinggi Agama Islam (STAI) Syamsul 'Ulum Gunungpuyuh \\ Sukabumi, Jawa Barat, Indonesia \\ warisnip.81@gmail.com
}

\begin{abstract}
Abstrak
Perceraian dalam Islam dibolehkan apabila suami istri menghadapi masalah sulit dan tidak bisa diselesaikan. Kerentanan dan gelombang perceraian semakin tinggi lonjakannya pada saat dihadapkan pada situasi sulit seperti masa Pandemi Covid-19, ketidaksiapan mental spiritual dan kemampuan menyelesaikan berbagai masalah keluarga. Kajian penelitian ini mengungkap efektivitas Perda No 9 Tahun 2014 tentang Ketahanan Keluarga terhadap fenomena kasus perceraian dari kurun waktu 20182020. Metode penelitian yang digunakan adalah pendekatan yuridis normatif. Berdasarkan kajian, salah satu upaya pemerintah dalam menekan angka perceraian dengan diterbitkannya Perda Nomor 9 Tahun 2014 tentang Ketahanan Keluarga dan dibentuknya motivator-motivator merupakan komitmen pemerintah yang luar biasa, namun ternyata perceraian bukan hal yang bisa diintervensi dan diselesaikan dengan regulasi sehingga Perda Nomor 9 Tahun 2014 tentang Ketahanan Keluarga dan dibentuknya motivator-motivator belum sepenuhnya efektif untuk menekan laju peningkatan perceraian.

Kata Kunci: Peraturan Daerah, Perceraian \& Ketahanan Keluarga
\end{abstract}

\begin{abstract}
Divorce in Islam is allowed when the husband and wife face difficult and unsolvable problems. The increase in vulnerability of divorce when faces difficult situations such as the Covid-19 Pandemic, mental and spiritual unpreparedness and the ability to solve various family problems. This research reveals to the effectiveness of Regional Regulation Number 9/2014 on Family Resilience to the phenomenon of divorce cases from the
\end{abstract}

Jurnal At-Tadbir: Media Hukum dan Pendidikan Volume 31 Nomor 1 Tahun 2021 
period 2018-2020. The research method used a normative juridical approach. Based on the research, one of the government's efforts to reduce the divorce rate with the issuance of Local Government Regulation Number 9 of 2014 on Family Resilience and the formation of motivators was an extraordinary government commitment, but in fact divorce is not something that can be intervened and resolved by regulation so that the Local Government Regulation Number 9 Year 2014 on concerning Family Resilience and the formation of motivators has not been fully effective in reducing the rate of increasing divorce.

Keywords: Regional Regulations, Divorce \& Family Resilience

\section{PENDAHULUAN}

Pemerintah Provinsi Jawa Barat telah berkomitmen menjadikan pembangunan ketahanan keluarga sebagai salah satu prioritas utama dalam pembangunan Jawa Barat, hal tersebut diperkuat dengan diterbitkannya Perda No. 9 Tahun 2014 tentang penyelenggaraan pembangunan ketahanan keluarga dalam rangka mencapai kesejahteraan, kebahagiaan lahir dan batin seluruh anggota keluarga tersebut sehingga diperlukan sebuah proses dan upaya yang terus menerus yang dilakukan pemerintah untuk dapat meningkatkan kualitas hidup dan penghidupan keluarga (Sunarti, 2014).

\begin{tabular}{lrr}
\multicolumn{2}{c}{ Perkembangan } & era \\
globalisasi & sekarang & ini \\
memberikan & pengaruh & pada
\end{tabular}

tatanan kehidupan keluarga dan masyarakat di bidang sosial, ekonomi, budaya dan teknologi informasi. begitu banyak fenomena sosial yang memperlihatkan tatanan keluarga yang tidak utuh akibat terjadinya kerapuhan keluarga, sebagai contoh tingkat perceraian yang cenderung meningkat (http://dp3akb.jabarprov.go.id/up grading-trainer-motivator-

ketahanan-keluarga-motekartahun-2020/ ).

Tahun 2020 menurut data yang diperoleh dari Badan Pusat Statistik (BPS) Provinsi Jawa Barat menempati urutan kedua sebagai provinsi dengan angka perceraian tertinggi di Indonesia. Menempati urutan pertama Provinsi Jawa Timur, dan Jawa Tengah berada di urutan ketiga di Indonesia dalam jumlah kasus 
Efektivitas Peraturan Daerah Nomor 9 Tahun 2014 tentang

di Jawa Barat (Rinrin Warisni Pribadi)

perceraian di 2019. Juni dan Juli. Jika di analisis kasus

(www.bps.go.id)

Pertengahan tahun 2020 ajuan cerai pada bulan-bulan sebelumnya, jumlah ajuan cerai viral video di media sosial baik di laman facebook, instragam yang memperlihatkan antrean panjang warga di Pengadilan Agama Soreang, Kabupaten Bandung. Antrean panjang tersebut merupakan antrean pengajuan gugatan cerai dan tentunya pihak perempuan yang mengajukan gugatan tersebut.

Seperti yang diketahui pengajuan perceraian di Pengadilan Agama ada dua jenis, yaitu cerai talak yang diajukan oleh pihak suami dan cerai gugat yang diajukan oleh pihak istri (Arto, 2000). Data yang poenulis dapat dalam layanan online di Pengadilan Tinggi Agama (PTA) Jabar, kasus cerai gugat hingga Senin $(7 / 9 / 2020)$ terdapat total 51.646 dan kasus cerai talak 17.397 yang telah diajukan dan diproses sejak Januari 2020 di PTA Jabar.

Dilihat dari data pada layanan online tersebut, kasus ajuan perceraian paling banyak ada di angka 12.603 kasus dan 11.778 kasus diajukan sekitar pertengahan tahun yakni di bulan berada pada kisaran angka 2.0008.000. Dan pada Januari 2020 kasus ajuan percerain sempat berada di angka 11.249 kasus.

Permasalahan diatas merupakan realitas sosial yang terjadi pada masyarakat Provinsi Jawa Barat, tingginya lonjakan perceraian menjadi masalah sosial cukup menarik untuk dikaji terlebih setelah Pemerintah Provinsi Jawa Barat membuat Perda sebagai ikhtiar maksimal meredam tingginya lonjakan perceraian. Dalam kajian ini penulis mencoba menganalisa dari berbagai aspek faktor penyebab seperti religiusitas, komunikasi dalam keluarga, ekonomi dan tinjauan terhadap efektivitas Perda Nomor 9 tahun 2014 tentang penyelenggaraan pembangunan ketahanan keluarga dalam upaya menekan angka perceraian di jawa barat dan point terakhir terkait Perdan Nomor 9 tahun 2014 menjadi titik fokus penulis dalam tulisan ini terutama menyakut efektifitasnya dalam meredam lonjakan perceraian di Jawa Barat. 


\section{METODE PENELITIAN}

Penelitian ini menggunakan pendekatan yuridis normatif yaitu dengan melakukan analisis terhadap permasalahan dalam penelitian melalui pendekatan asas-asas hukum serta mengacu kepada norma-norma hukum yang terdapat dalam peratuaran perundang-undangan di Indonesia. Selai itu penelitian ini juga termasuk ke dalam penelitian hukum sosiologis atau empirik. Adapun yang termasuk ke dalam hukum sosiologis atau empiric ialah penelitian identifikasi hukum tidak tertulis dan penelitian efektivitas hokum.

Pendekatan-pendekatan yang dipergunakan dalam penelitian ini adalah: Pertama, pendekatan Yuridis, artinya penelitian terhadap produk hukum yang menjadi Peraturan Daerah (Perda). Kedua, pendekatan Historis artinya telaah terhadap perkembangan dan penerapan peraturan-peraturan daerah sebagai hukum materiilnya. Ketiga, pendekatan Sosiologis, yaitu pendekatan yang memusatkan perhatiannya pada kehidupan kelompok dan tingkah laku sosial beserta produk kehidupannya (Soekanto,1995).

\section{HASIL PEMBAHASAN \\ A. Perceraian Dalam Islam dan Undang-undang No.01 Tahun 1974. \\ Islam memandang} pernikahan merupakan satu ikatan kuat dan sakral antara seorang laki-laki dengan perempuan. Tujuan pernikahan yang sangat mulia ini adalah terwujudnya keluarga yang sakinah, mawaddah dan warrohmah. Namun apabila tujuan tersebut tidak tercapai dan tidak bisa diselesaikan, hingga banyak

menhadirkan kemadharatan bagi pasangan suami istri, Islam menganjurkan untuk menyelesaikan secara ma'ruf (baik). Perceraian merupakan perilaku yang Allah benci namun diperbolehkan jika memang tidak ada jalan lain untuk menyelamatakan pernikahan tersebut atau pernikahan tersebut mendatangkan kemudharatan yang lebih besar, maka perceraian merupakan jalan terakhir dan solusi terbaik. (Qaradhawi, 2011)

Dalam Islam putusnya ikatan pernikahan dikenal dengan istilah talak. Talak dapat terjadi 
dalam bentuk ungkapan yang jelas, permisalan atau sindiran yang dilakukan pihak suami kepada istrinya. Contoh yang dilakukan dalam bentuk ungkapan secara jelas, perkataan suami kepada istrinya, "Kamu aku ceraikan", adapun contoh perkataan suami kepada istri dalam bentuk sindiran, "Pergilah kepada keluargamu" (Al jazairy, 2001). Setelahnya barulah dikenal istilah perceraian atau cerai gugat. Hal ini merujuk pada Firman Allah : "Talak (yang dapat dirujuki) dua kali, setelah itu boleh rujuk lagi dengan cara yang ma'ruf atau menceraikan dengan cara yang baik," (QS. Al-Baqarah [2]: 229) dan Firman Allah Swt. pada ayat lainnya, "Hai Nabi, apabila kamu menceraikan istriistrimu maka hendaklah kamu ceraikan mereka pada waktu mereka dapat (menghadapi) iddahnya (yang wajar)" (QS. AthThalaq [65]: 1).

Talak dalam Islam bisa menjadi wajib hukumya, apabila banyak mendatangkan kemudharatan lebih besar daripada kemaslahatan dalam bahtera rumah tangga dan tentu keputusan itu diambil setelah berikhtiar dengan berbagai cara tidak menemukan titik temu dan solusi terbaik untuk mendamaikannya

(Ghozali, 2008). Hal ini berdasarkan pada kasuistik yang terjadi pada sahabat Nabi yang mengadukan persoalan kejahatan istrinya kepada Rasulullah saw dan Rasul pun Bersabda "Ceraikan dia," (Diriwayatkan Abu Daud. Hadis ini shahih).

Jika terjadi sebaliknya, talak malah mendatangkan mudharat bagi salah satu pihak baik suami atau istrinya, atau tidak mendatangkan manfaat dengan adanya talak. Maka hukum talak dalam kasus ini menjadi haram hukumnya. Rasulullah bersabda, "Istri mana pun yang meminta cerai kepada suaminya tanpa alasan, maka aroma surga diharamkan baginya," (Diriwayatkan seluruh penulis Sunan. Hadis ini shahih)

Merujuk pada realitas teks Al-Qur'an dan Sunnah serta aspek psiko-sosiologis suami istri menghadapi masalah keluarga yang cukup rumit dan sulit untuk diselesaikan dengan berbagai pendekatan hingga malah mendatangkan banyak madharat 
bagi eksistesi keluarga dalam hal ini suami dan istri maka perceraian satu satunya solusi penyelesaian dan Islam pun membolehkan, hal ini mengandung arti bahwa perceraian merupakan pilihan terakhir ketika memang tidak ada lagi jalan keluar lainnya bagi pasangan suami istri untuk mempertahankan mahligai rumah tangganya. Hal ini merujuk pada al-Quran dalam Qs. Al-Baqarah [2] ayat 227. Allah SWT berfirman:"Dan jika mereka berazam (bertetap hati untuk) talak, maka sesungguhnya Allah Maha Mendengar lagi Maha Mengetahui."

Dalam Undang-Undang Nomor 1 Tahun 1974 Bab VIII tentang perceraian atau putusnya perkawinan serta akibatnya, pasal 38 menegaskan bahwa perkawinan dapat putus karena: kematian, perceraian, dan atas keputusan Pengadilan 1 . Selanjutnya pasal 39 ayat 1 menegaskan bahwa: Perceraian hanya dapat dilakukan di depan sidang Pengadilan setelah Pengadilan yang bersangkutan berusaha dan tidak berhasil mendamaikan kedua belah pihak. (Isnaeni, 2016)

Tujuan dari pasal 39 ayat 1 adalah untuk mempersulit dan mengurangi terjadinya perceraian (Mudzhar, 2003). Dalam perspektif Undang-Undang Nomor 1 Tahun 1974 di atas, perceraian dilakukan suami istri karena sesuatu yang dibenarkan oleh Pengadilan melalui persidangan.

Sehubungan dengan Undang-Undang Nomor 1 Tahun 1974, pasal 65 Undang-Undang Peradilan Agama Nomor 7 Tahun 1989 yang telah diubah dengan Undang-Undang

Republik Indonesia Nomor 3 Tahun 2006 Jo Pasal 39 Undang-Undang Nomor 1 Tahun 1974 juga ditegaskan bahwa: "Perceraian hanya dapat dilakukan di depan sidang Pengadilan setelah pengadilan yang bersangkutan berusaha dan tidak berhasil mendamaikan kedua belah pihak. Alasan mengapa hukum perkawinan di Indonesia mengatur bahwa suatu perceraian itu harus dilakukan di depan sidang Pengadilan, dan tidak diakui perceraian yang dilakukan di luar Pengadilan. Dalam penjelasan umum Undang- 
Efektivitas Peraturan Daerah Nomor 9 Tahun 2014 tentang

di Jawa Barat (Rinrin Warisni Pribadi)

Undang Nomor 7 Tahun 1989 tentang Peradilan Agama dijelaskan bahwa UndangUndang Perkawinan bertujuan antara lain untuk melindungi kaum wanita pada umumnya dan pihak istri pada khususnya. Disamping itu secara yuridis Undang-Undang tersebut bertujuan adalah untuk mendapatkan suatu kepastian hukum. Selain Undang-Undang Nomor 1 Tahun 1974 dan Undang-Undang Peradilan Agama Nomor 7 Tahun 1989, Kompilasi Hukum Islam Bab XVI pasal 115 juga menyebutkan: Perceraian hanya dapat dilakukan di depan sidang Pengadilan Agama setelah Pengadilan Agama tersebut berusaha dan tidak berhasil mendamaikan kedua belah pihak. Pengaturan perceraian yang dirumuskan dalam Kompilasi Hukum Islam Bab XVI merupakan perluasan atas aturan yang ditetapkan dalam Bab VIII Undang-Undang Nomor 1 Tahun 1974, Bab IV dan Bab V Peraturan Pemerintah Nomor 9 Tahun 1975 Tentang Pelaksanaan UndangUndang Nomor 1 Tahun 1974. Hal-hal yang dibicarakan diantaranya adalah campur tangan
Pengadilan dalam perceraian, yakni: (Bisri, 1999).

1. Perceraian hanya dapat dilakukan di depan sidang Pengadilan Agama;

2. Bentuk perceraian terdiri atas cerai talak dan cerai gugat. Dalam hal ini hak untuk memecah perkawinan melalui perceraian tidak hanya menjadi monopoli suami, istri diberi hak mengajukan cerai gugat;

3. Perceraian di luar Pengadilan Agama tidak sah dan tidak mengikat (cerai liar).

\section{B. Peraturan Daerah Provinsi Jawa Barat Nomor 9 Tahun 2014}

Perda_Ketahanan Keluarga di Jawa Barat yang merupakan Perda pertama di Indonesia. Perda ini dibuat, Pusat Pelayanan Terpadu Pemberdayaan Perempuan dan Anak (P2TP2A) Jawa Barat. P2TP2A ingin melakukan berbagai upaya dari hulu ke hilir tidak hanya bertindak di ruang-ruang rehabilitasi saja. Lebih utama adalah membangun kesadaran dan kepedulian betapa pentingnya ketahanan keluarga untuk mewujudkan tujuan pernikahan yaitu keluarga yang sakinah, mawaddah dan 
Efektivitas Peraturan Daerah Nomor 9 Tahun 2014 tentang

di Jawa Barat (Rinrin Warisni Pribadi)

warrohmah di kalangan masyarakat.

Dalam Perda No 9 Tahun 2014 Pasal 1 Ayat ke 8 dan 9, Keluarga merupakan bagian terkecil dalam masyarakat bisa hanya suami dan istri, atau suami, istri dan anaknya, atau ayah dan anaknya, atau ibu dan anaknya. Kondisi dinamik suatu keluarga yang memiliki keuletan dan ketangguhan serta mengandung kemampuan fisik materiil dan psikis mental spiritual guna hidup mandiri dan mengembangkan diri dan keluarganya untuk hidup harmonis dalam meningkatkan kesejahteraan lahir dan kebahagiaan batin adalah pengejawantahan dari makna ketahanan Keluarga.

Ketahanan keluarga meliputi beberapa aspek, yaitu; 1. Kebutuhan sandang seperti pakaian, pangan meliputi makanan yang halal dan thoyib (baik), sehat, memenuhi kebutuhan nutrisi, serta papan mencakup rumah tempat tinggal yang layak sesuai kemampua) dapat dipenuhi dengan baik sebagai upaya ketahanan fisik. Kewajiban setelah adanya aqad nikah yang telah diikrarkan oleh suami, maka suami mempunyai kewajiban memberikan nafkah untuk memenuhi kebutuhan hidup, sandang, pangan dan papan, bagi isteri dan anakanaknya.

2. Sebagai upaya pemenuhan ketahan non fisik, maka suami wajib memberikan nafkah batin kepada isterinya, dan isteri wajib memenuhi hak-hak suaminya. Kemudian suami berupaya memenuhi kebutuhan mental ruhaniah-psikologis dari pasangan dan anak-anak yang dilahirkannya meliputi terpenuhinya rasa aman dan terlindungi, tenteram, penuh cinta dan kedamaian-sakinah mawaddah wa rahmah..

3. Ketahanan sosial yaitu terpeliharanya hubungan fungsional dengan orang tua dan sanak keluarga, serta dengan komunitas di lingkungannya.

4. Ketahanan di bidang agama dan hukum yaitu ketaatan terhadap ketentuan agama dan hukum yang mengatur hak dan kewajiban suami dan isteri, orang tua dan anak-anak

\section{Efektivitas Perda No 9 Tahun 2014}

Kata efektif berasal dari bahasa Inggris yaitu effective 
yang berarti berhasil atau suatu kegiatan atau pekerjaan yang dilakukan berhasil dengan baik. Kamus ilmiah populer mendefinisikan efetivitas sebagai ketepatan penggunaan, hasil guna atau menunjang tujuan. (KBBI, 2016)

Menurut pendapat Mahmudi mendefinisikan efektivitas, sebagai berikut:"Efektivitas merupakan hubungan antara output dengan tujuan, semakinbesar ontribusi (sumbangan) output terhadap pencapaian tujuan, makasemakin efektif organisasi, program atau kegiatan” (Mahmudi, 2005). Efektivitas difokuskan pada keberhasilan outcome (hasil) dari satu kegiatan, pekerjaan atau program yang dinilai efektif, output dikatakan efektiv jika yang dihasilkan dapat memenuhi tujuan sesuai dengan yang diharapkan atau dikatakan spending wisely.

Merespon lonjakan tingginya angka kasus perceraian di Jawa Barat, Pemerintah propinsi berupaya maksimal dengan membuat Perda Nomor 9 Tahun 2014 Dalam Pasal 4 penyelenggaraan pembangunan ketahanan keluarga bertujuan untuk terwujudnya kualitas keluarga dalam memenuhi kebutuhan fisik material dan mental spiritual secara seimbang sehingga dapat menjalankan fungsi keluarga secara optimal menuju keluarga sejahtera lahir serta batin.

Di antara wujud implementasi dari Perda tersebut adalah dibentuk unit kerja MOTEKAR

(Motivator Ketahanan Keluarga) yang merupakan kader pemberdayaan masyarakat yang berasal dari masyarakat desa/kelurahan setempat, yang memiliki pengetahuan, kemauan, dan kemampuan untuk memfasilitasi kegiatan pemberdayaan keluarga pra-sejahtera dan perempuan dalam meningkatkan kualitas hidupnya dan keluarganya agar lebih baik. Senada dengan itu bahwa pembentukan Motivator Ketahanan Keluarga (Motekar) adalah untuk membantu penanganan permasalahan kerentanan keluarga yang merupakan faktor terbesar penyebab terjadinya perceraian (Hasanah dan Komariah, 2019). Ketidakmampuan keluarga dalam merespon situasi 
krisis/konflik/darurat merupakan kerentanan keluarga (Sunarti, 2014). Kerentanan keluarga berkaitan erat dengan bagaimana keluarga dapat menghadapi berbagai ancaman atau gangguan yang dapat menganggu kestabilan dan kesejahteraan keluarga. Beberapa hal kondisi yang menjadi pemicu kerentanan keluarga diantaranya karena faktor ekonomi, sosial budaya dan psikologis, seperti akibat tidak memiliki pekerjaan dan penghasilan yang cukup, gizi buruk dan penyakit, ketidakbijakan dalam menggunakan teknologi, kurangnya pendidikan dan keterampilan, perceraian dan ketidakharmonisan dalam keluarga, pola asuh dan kasus kekerasan kepada anak, gaya hidup dan pergaulan yang materialistis, kurangnya pemahaman agama dan religi dan berbagai kondisi lain yang dapat mengancam ketahanan dan kesejahteraan keluarga.

\section{Sunarti}

mengungkapkan bahwa ketahanan keluarga merupakan kemampuan keluarga dalam mengelola masalah yang dihadapi berdasarkan sumberdaya yang dimiliki untuk memenuhi kebutuhan keluarganya. Adapun indikator umum ketahanan keluarga dibagi kedalam tiga aspek yaitu ketahanan fisikekonomi, ketahanan psikologis, dan ketahanan sosial.

1. Ketahanan fisik-ekonomi berkaitan dengan kemampuan ekonomi keluarga yang merupakan kemampuan anggota keluarga dalam memperoleh sumberdaya ekonomi dari luar sistem keluarga guna memenuhi kebutuhan dasar seperti sandang, pangan, perumahan, pendidikan, dan kesehatan. Keluarga dapat dikatakan telah memiliki ketahanan apabila pendapatan perkapita melebihi kebutuhan fisik minimum (sandang, pangan, papan) dan atau lebih dari satu orang bekerja dan memperoleh sumberdaya ekonomi melebihi kebutuhan fisik dan kebutuhan perkembangan seluruh anggota keluarga.

2. Ketahanan sosial berkaitan dengan kekuatan keluarga dalam menerapkan aturan dan nilai dalam konteks agama, memelihara ikatan dan komitmen dalam berumah tangga, menciptakan 
komunikasi yang efektif dalam hubungan suami, istri dan anakanak, membagi peran dalam rumah tangga sesuai fitrahnya, menetapkan tujuan jangka panjang bukan sekedar di dunia, saling memotivasi yang dijadikan sumber kekuatan dalam menghadapi masalah dan rintangan dalam berkeluarga, juga memiliki hubungan dakam masyarakat yang positif. Ketahanan sosial terdiri dari sumberdaya non-fisik, mekanisme penganggulangan masalah yang baik, berorientasi pada nilai-nilai agama, efektif dalam berkomunikasi, senantiasa memelihara hubungan sosial, serta memiliki penanggulangan krisis atau masalah.

3. Ketahanan psikologis adalah bagaimana anggota keluarga mempunyai kemampuan untuk mengelola emosinya sehingga dihasilkan konsep diri yang positif, mendapatkan kekuatan, serta kepuasan terhadap pemenuhan kebutuhan dan pencapaian tugas perkembangan keluarga.

Kemampuan menghadapi masalah-masalah keluarga yang bersifat non-fisik seperti masalah yang tidak berkaitan dengan materi seperti masalah komunikasi sehingga terjadi kesalahpahaman, konflik suami dan istri, dan kuncinya adalah Kemampuan mengelola emosi dan konsep diri yang baik. Keluarga dikatakan memiliki ketahanan psikologis apabila anggota keluarga memiliki konsep diri dan emosi yang positif. Syarat utama untuk tercapainya ketahanan psikologis adalah kepribadian yang matang dan kecerdasan emosi pasangan suami dan istri.

Upaya pemerintah dalam menekan angka perceraian dengan diterbitkannya Perda, dibentuknya motivator-motivator merupakan komitmen pemerintah yang luar biasa. Namun ternyata perceraian bukan hal yang bisa diintervensi dan diselesaikan dengan regulasi. Mengingat penyebab perceraian dalam beberapa tahun terakhir ini yang paling tinggi disebabkan karena faktor komunikasi, ekonomi dan ketidakcocokan.

Selama pandemi COVID-19 jika melihat data dari layanan online resmi Pengadilan Agama Bandung, dalam portal SiKABAYAN (kabayan.ptabandung.go.id) tercatat Hingga 29 
Efektivitas Peraturan Daerah Nomor 9 Tahun 2014 tentang di Jawa Barat (Rinrin Warisni Pribadi)

Agustus 2020, terjadi 55.876 angka gugatan perceraian, sehingga dapat dikatakan kasus perceraian di Jawa Barat meningkat pesat selama masa pandemi. Lebih spesifik, lonjakan angka gugatan yang terjadi pada rentang Mei-Juni-Juli selama pemberlakuan masa awal Pembatasan Sosial Berskala Besar (PSBB) dilakukan.

Dari jumlah kasus gugatan yang masuk sekitar 2.734 pada Mei 2020 melonjak ke angka 12.617 pada Juni begitu pun pada Juli tercatat angka gugatan mencapai 11.797 gugatan. Hal ini terjadi di semua satuan kerja Pengadilan Agama di Jawa Barat.

Seperti diketahui, gugatan cerai merupakan cara istri untuk mengajukan cerai terhadap suami melalui Pengadilan Agama, dalam Islam istilah ini disebut dengan khulu (Pasal 148 ayat (1) KHI) (Arto, 2000). Sementara itu angka permohonan cerai atau talak yang dilakukan suami pada bulan Mei di Jawa Barat mencapai angka 412, sedangkan pada Juni meningkat ke angka 1.782. Di bulan Juli 2020 permohonan cerai juga bertambah yakni,2.286 kasus sehingga terjadi peningkatan.
Total kasus selama rentang Januari 2020 hingga Agustus 2020 terjadi 55.876 kasus perceraian. Faktor-faktor penyebab terbanyak dari pengajuan gugatan perceraian tersebut adalah perselisihan dan pertengkaran antara suami dan istri yang terjadi secara terus menerus merupakan faktor yang paling dominan. Jika diurutkan sesuai data statistic yang didapat dari laman online PTA Bandung pertengkaran dan perselisihan terus menerus sebanyak 34646 kasus menjadi alasan pertama penyebab perceraian, dilanjutkan alasan ekonomi sebanyak 27565 kasus, dan meninggalkan istri atau suami sebanyak 2846 kasus (data statistik pada laman ptabandung.go.id).

Analisis dari Kepala Perwakilan Badan Kependudukan dan Keluarga Berencana Nasional (BKKBN) Jawa Barat, Uung Kusmana, penyebab angka perceraian saat ini adalah karena efektivitas komunikasi dalam keluarga yang belum handal. Selain itu, berbagai macam ujian pada pasangan suami istri, seperti Pemutusan Hubungan Kerja (PHK) yang menyebabkan 
Efektivitas Peraturan Daerah Nomor 9 Tahun 2014 tentang

di Jawa Barat (Rinrin Warisni Pribadi)

terganggunya

stabilitas

perekonomian keluarga.

\section{KESIMPULAN}

Berdasarkan data dan fakta yang penulis himpun dan analisa dapat disimpulkan bahwa Perceraian dalam Islam dibolehkan apabila suami istri menghadapi masalah keluarga yang sulit untuk diselesaikan dengan berbagai pendekatan dan hanya perceraian merupakan pilihan terakhir untuk menyelesaikannya. Penerbitan Perda Nomor 9 Tahun 2014 Ketahanan Keluarga menjadi upaya dalam menekan kerentanan dan gelombang perceraian yang semakin tinggi lonjakannya pada saat dihadapkan pada situasi sulit seperti masa Pandemi Covid-19 saat ini. Dalam Pasal 4 Penyelenggaraan pembangunan ketahanan keluarga bertujuan untuk: terwujudnya kualitas keluarga dalam memenuhi kebutuhan fisik material dan mental spiritual secara seimbang sehingga dapat menjalankan fungsi keluarga secara optimal menuju keluarga sejahtera lahir serta batin, merupakan keputusan yang tepat dan sangat efektif, hanya tinggal bagaiman memaksimalkan implementasinya di lapangan.

\section{DAFTAR PUSTAKA}

Al-Jazairy, Abu Bakar Jabir. (2001). Ensiklopedi Muslim (Minhajul Muslim). Jakarta: Darul Falah.

Arto, Mukti. (2000). Praktek Perkara Peradilan Pada Pengadilan Agama. Yogyakarta: Pustaka Pelajar.

Bisri, Cik Hasan. (2000). Peradilan Agama di Indonesia. Jakarta: Raja Grafindo Persada.

Data Statistik faktor penyebab perceraian diakses pada tanggal 02 Oktober 2020 jam 10.00 dari laman http://kabayan.ptabandung.go.id/pengawasan_sipp/

Data Statistik Perceraian tertinggi di Indonesia diakses pada tanggal 30 September 2020 jam 13.00 dari laman https://www.bps.go.id/indikator/indikator/view_data_pub/3200/api_ pub/110/da_04/1 
Faktor yang berpengaruh terhadap tingginya perceraian di Jawa barat diakses pada tanggal 30 September 2020 jam 13.00 dari laman http://dp3akb.jabarprov.go.id/upgrading-trainer-motivatorketahanan-keluarga-motekar-tahun-2020/

Ghozali, Abdul Rohman. (2008). Fiqh Munakahat. Jakarta: Prenadamedia. Hasanah, Viena Rusmiati, dan Komariah, Dede Nurul. (2019) MOTEKAR (Motivator Ketahanan Keluarga) dan Pemberdayaan Keluarga Rentan PAUD Lectura: Jurnal Pendidikan Anak Usia Dini, Vol 02, No 02, April.

Isnaeni, Moch. (2016). Hukum Perkawinan Indonesia. Bandung: Refika Aditama.

Kemendikbud (2016). KBBI. Jakarta: Balai Pustaka.

Mahmudi. (2005). Manajemen Kinerja Sektor Publik. Jakarta: UPP STIM YKPN.

Mudzhar, M. Atho. (1999). Studi Hukum Islam dengan Pendekatan Sosiologi. Yogyakarta: IAIN.

Peraturan Daerah Nomor 9 Tahun 2014 Tentang Penyelenggaraan Pembangunan Ketahanan Keluarga.

Soekanto Soerjono dan Sri mamudji, (1995). Penelitian Hukum Normatif Suatu Tinjauan Singkat, Jakarta: Raja Grafindo Persada.

Sunarti, E. (2014). Modul Ketahanan Keluarga Bagi MOTEKAR (Motivator Ketahanan Keluarga di Jawa Barat). Bandung: BP3AKB.

Undang-undang Nomor 01 Tahun 1974 Tentang Perkawinan

Qaradhawi, Yusuf. (2011). Halal dan Haram. Jakarta: Rabbani Press. 